- e ISSN-0976-6855 | Visit us : www.researchjournal.co.in

\title{
Compatibility of phosphate solubilizing fungi with agro chemicals
}

S.B. SHINDE* AND M.D. SADGIR

Department of Plant Pathology, Post Graduate Institute, Dr. Panjabrao Deshmukh Krishi Vidyapeeth, AKOLA (M.S.) INDIA

\section{ARITCLE INFO}

Received : 22.09 .2015

Revised : 05.02 .2016

Accepted : 19.02 .2016

\section{KEY WORDS :}

Compatibility, Agrochemical, Aspergillus niger, Aspergillus flavus

*Corresponding author:

Email: shindesb123@gmail.com

\begin{abstract}
Compatibility of Phosphate solubilizing fungi with agrochemicals were tested in vitro. The results indicated that Aspergillus niger and Aspergillus flavus were not compatible with fungicides i.e. thiram, carbendazim, mancozeb and propiconazole and herbicides i.e. glyphosate, quizalfop-ethyl and fenoaxaprop p ethyl, whereas COC + streptocycline, streptocycline and insecticides i.e. cypermethrin, emamectin benzoate and imidacloprid were found compatible.
\end{abstract}

How to view point the article : Shinde, S.B. and Sadgir, M.D. (2016). Compatibility of phosphate solubilizing fungi with agro chemicals. Internat. J. Plant Protec., 9(1) : 35-39. 